\title{
APPLICATION OF PROJECT MANAGEMENT METHODS AND TOOLS BY CHEMICAL INDUSTRY COMPANIES IN THE CZECH REPUBLIC
}

\author{
Jana Kostalova ${ }^{1}$, Libena Tetrevova ${ }^{2}$ \\ Department of Economy and Management of Chemical and Food Industries, Faculty of Chemical \\ Technology, University of Pardubice, Studentska 95, 53201 Pardubice, Czech Republic \\ E-mails: ${ }^{1}$ jana.kostalova@upce.cz (corresponding author); ${ }^{2}$ libena.tetrevova@upce.cz
}

\begin{abstract}
The article deals with the application of project management methods and tools by chemical industry companies in the Czech Republic. There are identifiedsignificant project management methods and tools and classifies them with respect to their primary applicability within individual project lifecycle stages. In results, there is presented the level of project management in the Czech Republic. Subsequently, there are presented outcomes of a qualitative research focussed on the application of project management methods and tools in chemical industry companies in the Czech Republic. The authors also present proposals of methodical measures for the area of project management to improve the success of implemented projects.
\end{abstract}

Keywords: project management; project management methods and tools; European Funds projects; chemical industry companies; Czech Republic.

JEL Classification: F36, H29, L29, O19.

\section{Introduction}

In the present permanently changing environment of the economic world, each entrepreneurial entity can only prosper and exist in the future on condition that it is able to implement changes quickly, effectively, and in a suitable way. And project management $(\mathrm{PM})$ is what is considered a more and more important change management tool. Using PM, companies can implement a number of changes in all the areas of corporate activity. Application of PM methods and tools seems particularly significant in companies of those national economy industries that are of strategic importance, technologically interconnected, and capital intensive. Such companies include e.g. chemical industry companies.

The possibility of implementation of projects using financial support of the European Union nowadays represents a significant opportunity for all business entities, not excepting chemical industry companies. The European Union sources represent an alternative source of financing of corporate activities, which is connected with minimal acquisition and maintenance costs compared to the other types of corporate capital. Companies can obtain these sources both from the position of a solver of a project co-financed by European Funds (EF) and from the position of a partner of public and not-for-profit sector entities. In view of the capital intensity of chemical industry compa- nies, their innovation potential, and the number of risks relating to their activity, perceived by the professional and lay public as a society-wide problem, projects co-financed by EF represent an interesting opportunity just for chemical industry companies.

Nevertheless, the fact is that the success of project implementation, both in projects generally and consequently in projects co-financed by $\mathrm{EF}$, is determined by the level of PM. That is affected by the rate of knowledge and scope of application of PM methods and tools, which is perceived as a significant problem, especially in the post-communist EU member states of Central and East Europe (Katsarova, 2013). The authors aim to analyze and evaluate the application of PM methods and tools by selected chemical industry companies in the Czech Republic and to propose methodical measures to improve PM in these companies, both in the area of projects generally, and in the area of projects co-financed by EF.

\section{Review of the scientific literature}

\subsection{Project management methods and tools}

As time passed, a number of methods and tools have been developed specifically for the needs of PM. Further methods and tools were taken over from other scientific branches. Their application

(C) 2018 The Authors. Published by VGTU Press. This is an open-access article distributed under the terms of the Creative Commons Attribution License (CC-BY 4.0), which permits unrestricted use, distribution, and reproduction in any medium, provided the original author and source are credited. 
aims to ensure efficient project implementation and to decrease the risk of not finishing the project or exceeding the limits given by the triple imperative of the project (Atkinson, 1999). The scientific literature offers a wide range of PM methods and tools, which can be classified e.g. from the point of view of their primary applicability in individual project lifecycle stages. However, a number of PM methods and tools can subsequently be used in other project lifecycle stages, and some of them are then applicable within the entire project lifecycle (Patanakul, Iewwongcharoen, \& Milosevic, 2010).

In the case of a need for implementation of a certain project, it is necessary to formulate a project intent, and it is also necessary to assess this project intent from the point of view of its impact on implementation of the strategic targets of the company, to perform its financial assessment, to judge its feasibility from the point of view of the sources, and to assess the potential risks of the given project. Provided that more projects are being implemented at the same time, it is necessary to make a comparison in relation to the other implemented or planned projects with respect to the limited sources and the benefits of implementation of the project. To formulate and assess the project intent, it is possible to use the Feasibility Study (Hapanova \& Al-Jiburi, 2009), the SWOT Analysis (Robbins \& Coulter, 2004), methods for assessment of the effectiveness of investment projects with financial benefits, e.g. in the form of the Net Present Value (Tetrevova, 2006) and the Cost-Benefit Analysis (Tetrevova, 2008). Once the project intent is assessed positively, it is necessary to specify the project objective sufficiently precisely, for which it is possible to use the SMART Method (Maylor, 2010) or the Logical Framework Matrix (Barker \& Cole, 2007).

In the project planning stage, it is necessary to specify all the project parameters precisely in the way to make it possible for the implementation stage to plan how to implement and check the project, and how it will be fulfilled as precisely as possible (Project Management Institute, 2004). To draw up a detailed plan, it is possible to use mainly methods based on a hierarchical structure, i.e. the Product Breakdown Structure (Association for Project Management, 2012), the Work Breakdown Structure (Norman, Brotherton, \& Fried, 2008), the Resource Breakdown Structure (Association for Project Management, 2012) and the Risk Breakdown Structure (Project Management Institute, 2004). It is also possible to use the network analysis methods - the Critical Path Method (Ravindran, 2008), the Program Evaluation and Review Technique (Trietsch \& Baker, 2012), the Metra Potential Method (Ravindran, 2008), the Critical Path Method/Cost (Hillier \& Lieberman, 2005) or the Graphical Evaluation and Review Technique (Pitas et al., 2012). It also seems purposeful to use such methods and tools like the Gantt Chart (Veber et al., 2009), the Critical Chain Method (Goldratt, 1999), source management methods (the Resource Levelling (Gross, 2009), the Responsibility Assignment Matrix (Melnic \& Puiu, 2011) and the Stakeholder Analysis (Svozilova, 2011), risk management methods (the Risk Project Analysis (Lacko, 2014), the Ishikawa Diagram (Project Management Institute, 2004)), the Determination of the Expected Value of the Risk (Dolezal et al., 2012), the Decision Tree Analysis (Svecova, 2013), and the Monte Carlo Method (Association for Project Management, 2012).

In the course of project implementation, when the planned activities and outputs are, in accordance with the drawn up plans, gradually implemented, the important methods and tools mainly include those leading to monitoring and comparing the actual status of the project to the plan and management of any potential changes. To monitor the project development, it is possible to use e.g. the Project Percent Complete Method (Maylor, 2010), the Structured Status Deviation (Lee-Kwang \& Favrel, 1988), the Milestone Trend Analysis (Dolezal et al., 2012), or the Earned Value Management (Solanki, 2009; Storms, 2008). It is also possible to make use of monitoring of costs in comparison with the budget (Meredith \& Mantel, 2012), and monitoring of the course of the project cash flow in comparison with its plan (Maravas \& Pantouvakis, 2012).

Even after completion of the project, in the stage of utilization of the project outputs, it is purposeful to apply some PM methods and tools, particularly the method of Lessons Learned (Carrilo, Ruikar, \& Fuller, 2013; Jugdev, 2012).

In the course of the entire project lifecycle, it is possible to use tools affecting organizational aspects of PM in the form of the organizational standards to support PM (Zandhuis \& Stellingwerf, 2013) and the project management office (PMO) (Müller, Glückler, \& Aubry, 2013; Unger, Gemünden, \& Aubry, 2012). An important tool penetrating the entire project lifecycle is also the applied organizational structure, where it is possible to recommend utilization 
mainly of the matrix or project organizational structures (Blazek, 2014). It is also not possible to omit education of the staff in PM or utilization of outside advisors and project managers. In the entire course of the project lifecycle, it is also possible to apply the Agile Methods (Beck et al., 2001).

To support PM methods and tools, to document projects, and particularly in a multi-project environment, it is possible to make use of various types of software (SW) tools, from simple freeware applications and freeware cloud solutions to complex SW applications; see more e.g. in (Vitous, 2012).

\subsection{Application of project management methods and tools in the Czech Republic}

Application of PM methods and tools in the Czech Republic can be illustrated by the outcomes of surveys performed in the recent years. In the first half of 2012, there was a survey conducted by the Czech Project Management Association (Kratky et al., 2012), which mapped the success of implementation of projects and application of PM methods and tools in the period of 2011. The respondents of the above survey were 178 mostly project managers and portfolio managers operating across all the branches. A survey focussing specifically on the area of projects cofinanced by EF was conducted by Kostalova (2015) from February to April 2013, and it aimed to identify the level of knowledge and the rate of utilization of PM methods and tools in projects co-financed by EF. The respondents of this survey were 171 project managers, project coordinators, and project financial managers who were, in the Programming Period 2007-2013, involved in the solution of projects co-financed by EF.

According to the survey performed by the Czech Project Management Association (Kratky et al., 2012), the most widely applied PM methods and tools include the Critical Path Method, the Work Breakdown Structure, and the financial evaluation of the project. On the other hand, the least commonly used methods and tools are the Critical Chain Method, the Earned Value Management, and the Agile Methods. According to the research performed by Kostalova (2015), the most widely applied PM methods and tools in projects co-financed by $\mathrm{EF}$ are the organizational standards to support PM, the PMO, and the Feasibility Study. On the other hand, the least commonly used methods and tools are the Agile Methods, the Work Breakdown Structure, and the Critical Chain Method. See more in (Ta- ble 1). Column "General Practice" shows the rate of utilization of the chosen PM methods and tools in the general practice, as it was identified by the survey conducted by the Czech Project Management Association. Column "EU projects" shows the rate of utilization of the above methods and tools by the solvers of projects cofinanced by EU funds, as it was identified by the survey conducted by Kostalova (2015).

Table 1. Utilization of the chosen PM methods and tools in the Czech Republic (source: Kostalova (2015) and Kratky et al. (2012))

\begin{tabular}{|c|c|c|}
\hline \multirow{2}{*}{$\begin{array}{l}\text { Project Management } \\
\text { Methods and Tools }\end{array}$} & \multicolumn{2}{|c|}{ Utilisation* } \\
\hline & $\begin{array}{l}\text { General } \\
\text { practice }\end{array}$ & $\begin{array}{c}\text { EU } \\
\text { projects }\end{array}$ \\
\hline Feasibility Study & $55.8 \%$ & $49.7 \%$ \\
\hline $\begin{array}{l}\text { Financial Evaluation of the } \\
\text { Project }\end{array}$ & $61.8 \%$ & $28.7 \%$ \\
\hline Logical Framework Matrix & $40.2 \%$ & $35.7 \%$ \\
\hline Work Breakdown Structure & $66.4 \%$ & $6.4 \%$ \\
\hline Critical Path Method & $66.7 \%$ & $28.7 \%$ \\
\hline Critical Chain Method & $16.8 \%$ & $7.0 \%$ \\
\hline Earned Value Management & $16.8 \%$ & $10.8 \%$ \\
\hline Formalized Risk Analysis & $61.3 \%$ & $40.8 \%$ \\
\hline $\begin{array}{l}\text { Formalized Project Commu- } \\
\text { nication Plan }\end{array}$ & $47.9 \%$ & $29.3 \%$ \\
\hline $\begin{array}{l}\text { Responsibility Assignment } \\
\text { Matrix }\end{array}$ & $61.3 \%$ & $26.8 \%$ \\
\hline $\begin{array}{l}\text { Organizational Standards to } \\
\text { Support PM }\end{array}$ & $42.1 \%$ & $60.1 \%$ \\
\hline Project Management Office & $42.7 \%$ & $56.3 \%$ \\
\hline Agile Methods & $19.8 \%$ & $3.8 \%$ \\
\hline
\end{tabular}

* Frequency representation of the respondents who stated within the survey that they use the given method or tool.

As for the SW tools to support PM methods and tools, according to the survey performed by the Czech Project Management Association (Kratky et al., 2012), 59\% of the respondents use an SW tool, and more than $65 \%$ of them use MS Project.

In view of the fact that the performed surveys focussing on application of PM methods and tools in the Czech Republic imply different rates of utilization of individual PM methods and tools in projects generally compared to projects co-financed by EF, it is possible to assume that economic entities, i.e. also the monitored chemical industry companies, have different approaches to management of these two types of projects and use different methods and tools for their 
management. The surveys performed so far also imply different rates of application of PM methods and tools from the point of view of individual PM areas, which can be divided into project time management, project source management, project cost management, project risk management, project scope management, project organizational arrangement (including education of the staff in PM), but also SW support of PM. Although the level of PM in the Czech Republic is not evaluated very positively compared to the foreign practice, see more e.g. in Ernst and Young (2013), Hrazdilova Bockova (2009), Kostalova, Tetrevova, and Patak (2015, 2017), it is possible to assume that each economic entity, i.e. also the monitored chemical industry companies, applies at least one PM method or tool in each of the above areas.

\section{Research methodology}

The paper drew on the outcomes of a secondary analysis aiming to map the current level of knowledge both in the area of specific and unspecific PM methods and tools and in the area of application of PM methods and tools in the Czech Republic. The secondary analysis was based on the literature review covering both books and papers, and conference proceedings. It also included documents published by trade associations in the area of PM. The choice of literature review sources was influenced by the relevance and currency of the given source.

The results of the secondary analysis are presented in the chapt. 2. Based on it, it is possible to formulate Hypotheses:

- Hypothesis H1 to be verified: The methods and tools applied by the monitored chemical industry companies within the management of projects cofinanced by EF are different from those they apply within the management of the other types of projects.

- Hypothesis H2: Each of the monitored chemical industry companies applies at least one of the assessed PM methods or tools in the areas of project time management, project source management, project cost management, project risk management, project scope management, project organizational arrangement (including education of the staff in PM), and SW support of PM.

To evaluate hypotheses the secondary analysis was followed by a qualitative survey. This survey was conducted with selected chemical industry companies in the Czech Republic which are solely or mostly involved in chemical production in the period of June - October 2014. It aimed to assess the scope of utilization of PM methods and tools by the selected chemical industry companies generally, and specifically in projects co-financed by EF. The survey was conducted in the form of directed interviews, on average 1.5 hours long and electronic and telephone communication. The information was obtained from persons responsible for PM and project managers of the selected companies.

The choice of companies was primarily based on the database of the members of the Association of Chemical Industry of the Czech Republic (Association of Chemical Industry of the Czech Republic, 2014) and subsequently on the database of the recipients of support from EF published by the Ministry of Regional Development of the Czech Republic as at 3 January 2014 (Ministry of Regional Development CZ, 2014), where the companies of the Association of Chemical Industry implementing projects cofinanced by EF were looked up. Representatives of the identified 23 companies were addressed in the given period. 12 of them responded to the possibility of taking part in the research. Finally, representatives of eight companies provided the information. Two representatives refused to provide the information due to the excessive details of the questions and publishing confidential information about the company, others due to high time demands, and the last stated that there is no responsible person to provide information about the given problems. With respect to the requirement of the company representatives concerning maintaining anonymity for the reason of stating sensitive information, individual companies are hereafter marked with letters A - H (Table 2) shows the basic information about the assessed companies.

Table 2. Basic data about the monitored companies (source: authors)

\begin{tabular}{|c|c|c|c|c|}
\hline 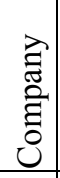 & $\begin{array}{l}\text { Legal } \\
\text { form }\end{array}$ & $\begin{array}{c}\text { Corporate } \\
\text { stock }\end{array}$ & $\begin{array}{c}\text { Number } \\
\text { of em- } \\
\text { ploy- } \\
\text { ees* }\end{array}$ & $\begin{array}{l}\text { No. of } \\
\text { appli- } \\
\text { cations } \\
* *\end{array}$ \\
\hline A & $\begin{array}{l}\text { coopera- } \\
\text { tive }\end{array}$ & CZK30m & 70 & $3 / 3$ \\
\hline B & $\begin{array}{l}\text { joint- } \\
\text { stock } \\
\text { company }\end{array}$ & $\begin{array}{l}\text { CZK1.027 } \\
\text { bn }\end{array}$ & 1000 & $10 / 9$ \\
\hline
\end{tabular}


End of Table 2

\begin{tabular}{|c|c|c|c|c|}
\hline 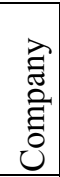 & $\begin{array}{l}\text { Legal } \\
\text { form }\end{array}$ & $\begin{array}{l}\text { Corporate } \\
\text { stock }\end{array}$ & $\begin{array}{c}\text { Number } \\
\text { of em- } \\
\text { ploy- } \\
\text { ees* }\end{array}$ & $\begin{array}{l}\text { No. of } \\
\text { appli- } \\
\text { cations } \\
* *\end{array}$ \\
\hline $\mathrm{C}$ & $\begin{array}{l}\text { joint- } \\
\text { stock } \\
\text { company }\end{array}$ & CZK1.6bn & 350 & $8 / 7$ \\
\hline $\mathrm{D}$ & $\begin{array}{l}\text { joint- } \\
\text { stock } \\
\text { company }\end{array}$ & CZK155m & 1200 & $5 / 3$ \\
\hline $\mathrm{E}$ & $\begin{array}{l}\text { joint- } \\
\text { stock } \\
\text { company }\end{array}$ & CZK1bn & 600 & $6 / 4$ \\
\hline $\mathrm{F}$ & $\begin{array}{l}\text { joint- } \\
\text { stock } \\
\text { company }\end{array}$ & CZK260m & 1600 & $9 / 3$ \\
\hline G & $\begin{array}{l}\text { limited } \\
\text { liability } \\
\text { company }\end{array}$ & CZK5m & 570 & $4 / 3$ \\
\hline $\mathrm{H}$ & $\begin{array}{l}\text { joint- } \\
\text { stock } \\
\text { company }\end{array}$ & CZK103m & 220 & $6 / 6$ \\
\hline
\end{tabular}

* rounded to whole tens.

**No. of applications for support from EF/No. of solved projects co-financed by EF.

The obtained information subsequently served as the basis for a proposal of methodical measures for chemical industry companies in the area of PM in general, and in the area of projects co-financed by $\mathrm{EF}$, which was also formulated using the findings of the literature review, the discussion with experts of the Czech Project Management Association, and with experts from the academic environment and the paper authors' practical experience with management of projects co-financed by EF.

\section{Results and discussion}

\subsection{Application of project management methods and tools by the monitored chemical industry companies}

The monitored companies were first researched to find out how much management of projects, in general, is different from management of projects co-financed by EF. On average, the monitored companies implemented, within the Programming Period 2007-2013, from 3 to 10 projects co-financed by EF, see more in (Table 2). In addition to that, some of the companies also implemented projects where the companies were in the position of a partner of different solvers of projects co-financed by EF. The company representatives stated that they approach the management of projects co-financed by EF similarly to the way they approach the management of other types of projects (financed by different sources) implemented in their organization.

Both for formulating and evaluation of project intents, defining project objectives, and within planning and implementation of projects, but also when applying outputs of projects cofinanced by EF, they apply the same PM methods and tools as in projects generally. The choice of particular PM methods and tools is not determined by the way of financing of the project, but by the character of a particular project from the point of view of its financial scope, time demands, or the material substance. However, two company representatives pointed out the dissimilarity consisting of higher time and administrative demands connected with meeting obligations set by the providers of support of projects cofinanced by EF. In spite of that, when managing projects co-financed by EF, also these companies apply the same methods and tools as in the management of projects generally. The above implies that Hypothesis H1 is not true.

Subsequently, the monitored companies were analyzed from the point of view of the application of PM methods and tools in the area of management of project time, sources, costs, risks, and scope, and within an organizational arrangement of projects, incl. education of workers in the area of PM. The analysis also included SW support of PM. (Table 3) shows the outcomes of the survey presented using the binary scale.

Table 3. Application of PM methods and tools by the monitored companies (source: authors)

\begin{tabular}{|c|c|c|c|c|c|c|c|c|c|c|}
\hline \multirow{2}{*}{ 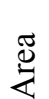 } & \multirow{2}{*}{$\begin{array}{l}\text { PM methods } \\
\text { and tools }\end{array}$} & \multicolumn{8}{|c|}{ Company } & \multirow{2}{*}{$\sum$} \\
\hline & & A & B & $\mathrm{C}$ & D & E & $\mathrm{F}$ & $\mathrm{G}$ & $\mathrm{H}$ & \\
\hline \multirow{5}{*}{ 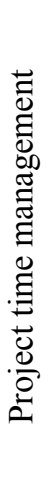 } & Gantt Chart & 0 & 0 & 1 & 0 & 0 & 1 & 0 & 0 & 2 \\
\hline & $\begin{array}{c}\text { Critical Path } \\
\text { Method }\end{array}$ & 0 & 0 & 1 & 0 & 0 & 1 & 0 & 0 & 2 \\
\hline & $\begin{array}{l}\text { Metra Potential } \\
\text { Method }\end{array}$ & 0 & 0 & 0 & 0 & 0 & 0 & 0 & 0 & 0 \\
\hline & $\begin{array}{l}\text { Program Evalu- } \\
\text { ation and Re- } \\
\text { view Technique }\end{array}$ & 0 & 0 & 0 & 0 & 0 & 0 & 0 & 0 & 0 \\
\hline & $\begin{array}{l}\text { Graphical Eval- } \\
\text { uation and Re- } \\
\text { view Technique }\end{array}$ & 0 & 0 & 0 & 0 & 0 & 0 & 0 & 0 & 0 \\
\hline
\end{tabular}




\begin{tabular}{|c|c|c|c|c|c|c|c|c|c|c|}
\hline \multirow{2}{*}{$\stackrel{\Xi}{⿺}$} & \multirow{2}{*}{$\begin{array}{l}\text { PM methods } \\
\text { and tools }\end{array}$} & \multicolumn{8}{|c|}{ Company } & \multirow{2}{*}{$\sum$} \\
\hline & & A & B & C & D & E & F & G & $\mathrm{H}$ & \\
\hline & $\begin{array}{l}\text { Critical Chain } \\
\text { Method }\end{array}$ & 0 & 0 & 1 & 0 & 0 & 0 & 0 & 0 & 1 \\
\hline & $\begin{array}{l}\text { Monte Carlo } \\
\text { Method }\end{array}$ & 0 & 0 & 0 & 0 & 0 & 0 & 0 & 0 & 0 \\
\hline & $\sum$ & 0 & 0 & 3 & 0 & 0 & 2 & 0 & 0 & 5 \\
\hline \multirow{5}{*}{ 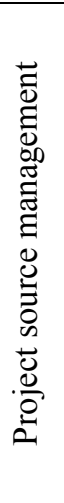 } & $\begin{array}{l}\text { Resource } \\
\text { Breakdown } \\
\text { Structure }\end{array}$ & 0 & 0 & 1 & 0 & 1 & 1 & 0 & 0 & 3 \\
\hline & $\begin{array}{l}\text { Resource } \\
\text { Levelling }\end{array}$ & 0 & 0 & 1 & 0 & 1 & 1 & 0 & 0 & 3 \\
\hline & $\begin{array}{c}\text { Responsibility } \\
\text { Assignment } \\
\text { Matrix } \\
\end{array}$ & 1 & 1 & 1 & 1 & 1 & 1 & 1 & 1 & 8 \\
\hline & $\begin{array}{l}\text { Stakeholder } \\
\text { Analysis }\end{array}$ & 0 & 0 & 0 & 0 & 1 & 0 & 0 & 1 & 2 \\
\hline & $\sum$ & 1 & 1 & 3 & 1 & 4 & 3 & 1 & 2 & 16 \\
\hline \multirow{6}{*}{ 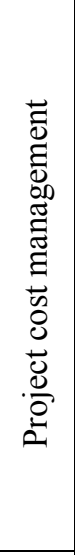 } & $\begin{array}{l}\text { Critical Path } \\
\text { Method/Cost }\end{array}$ & 0 & 0 & 0 & 0 & 0 & 1 & 0 & 0 & 1 \\
\hline & $\begin{array}{l}\text { Net Present } \\
\text { Value }\end{array}$ & 1 & 0 & 1 & 1 & 1 & 1 & 0 & 0 & 5 \\
\hline & $\begin{array}{l}\text { Cost-Benefit } \\
\text { Analysis }\end{array}$ & 0 & 1 & 0 & 0 & 0 & 1 & 0 & 1 & 3 \\
\hline & $\begin{array}{l}\text { Monitoring of } \\
\text { Project Costs }\end{array}$ & 1 & 1 & 1 & 1 & 1 & 1 & 1 & 1 & 8 \\
\hline & $\begin{array}{c}\text { Monitoring of } \\
\text { Project Cash } \\
\text { Flows } \\
\end{array}$ & 1 & 1 & 1 & 1 & 1 & 1 & 1 & 1 & 8 \\
\hline & $\sum$ & 3 & 3 & 3 & 3 & 3 & 5 & 2 & 3 & 25 \\
\hline \multirow{6}{*}{ 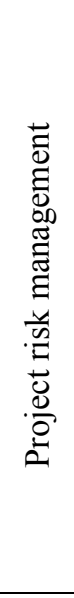 } & $\begin{array}{c}\text { Risk Break- } \\
\text { down Structure }\end{array}$ & 1 & 0 & 1 & 0 & 0 & 1 & 1 & 1 & 5 \\
\hline & $\begin{array}{l}\text { Risk Project } \\
\text { Analysis }\end{array}$ & 0 & 0 & 0 & 0 & 0 & 0 & 0 & 0 & 0 \\
\hline & $\begin{array}{l}\text { Ishikawa } \\
\text { Diagram }\end{array}$ & 0 & 1 & 1 & 0 & 0 & 1 & 0 & 0 & 3 \\
\hline & $\begin{array}{c}\text { Determination } \\
\text { of the Expected } \\
\text { Value of the } \\
\text { Risk }\end{array}$ & 1 & 0 & 1 & 0 & 0 & 1 & 1 & 1 & 5 \\
\hline & $\begin{array}{c}\text { Decision Tree } \\
\text { Analysis }\end{array}$ & 0 & 0 & 1 & 0 & 0 & 0 & 0 & 0 & 1 \\
\hline & $\sum$ & 2 & 1 & 4 & 0 & 0 & 3 & 2 & 2 & 14 \\
\hline \multirow{4}{*}{ 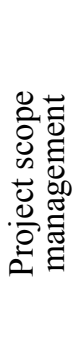 } & $\begin{array}{l}\text { SWOT } \\
\text { Analysis }\end{array}$ & 1 & 1 & 1 & 1 & 0 & 1 & 1 & 1 & 7 \\
\hline & $\begin{array}{l}\text { Feasibility } \\
\text { Study }\end{array}$ & 1 & 1 & 0 & 0 & 1 & 1 & 0 & 1 & 5 \\
\hline & $\begin{array}{l}\text { SMART } \\
\text { Method }\end{array}$ & 1 & 1 & 1 & 1 & 0 & 1 & 0 & 1 & 6 \\
\hline & $\begin{array}{c}\text { Logical Frame- } \\
\text { work Matrix }\end{array}$ & 0 & 0 & 1 & 0 & 0 & 0 & 0 & 0 & 1 \\
\hline
\end{tabular}

\begin{tabular}{|c|c|c|c|c|c|c|c|c|c|c|c|}
\hline \multirow{2}{*}{ 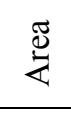 } & \multirow{2}{*}{$\begin{array}{c}\text { PM methods } \\
\text { and tools }\end{array}$} & \multicolumn{9}{|c|}{ Company } & \multirow{2}{*}{$\sum$} \\
\hline & & $\mathrm{A}$ & B & $\mathrm{C}$ & $\mathrm{D}$ & $\mathrm{E}$ & $\mathrm{F} / \mathrm{G}$ & $\mathrm{H}$ & A & B & \\
\hline & $\begin{array}{c}\text { Product } \\
\text { Breakdown } \\
\text { Structure }\end{array}$ & 0 & 0 & 0 & 0 & 0 & & 0 & 0 & 0 & 0 \\
\hline \multirow{8}{*}{ 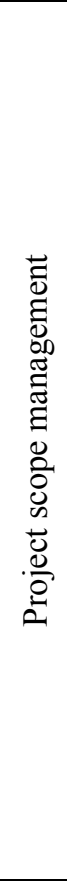 } & $\begin{array}{c}\text { Work } \\
\text { Breakdown } \\
\text { Structure }\end{array}$ & 0 & 0 & 0 & 0 & 0 & & 1 & 0 & 0 & 1 \\
\hline & $\begin{array}{c}\text { Project Per- } \\
\text { cent Com- } \\
\text { plete Method }\end{array}$ & 0 & 0 & 1 & 0 & 1 & & 0 & 0 & 1 & 3 \\
\hline & $\begin{array}{l}\text { Structured } \\
\text { Status } \\
\text { Deviation }\end{array}$ & 0 & 0 & 0 & 0 & 0 & & 0 & 0 & 0 & 0 \\
\hline & $\begin{array}{l}\text { Milestone } \\
\text { Trend } \\
\text { Analysis }\end{array}$ & 1 & 1 & 1 & 1 & 0 & & 1 & 0 & 1 & 6 \\
\hline & $\begin{array}{l}\text { Earned Value } \\
\text { Management }\end{array}$ & 0 & 0 & 1 & 0 & 0 & & 0 & 0 & 0 & 1 \\
\hline & $\begin{array}{l}\text { Lessons } \\
\text { Learned }\end{array}$ & 1 & 0 & 1 & 0 & 1 & & 1 & 0 & 1 & 5 \\
\hline & $\begin{array}{l}\text { Agile } \\
\text { Methods }\end{array}$ & 0 & 0 & 0 & 0 & 0 & & 1 & 0 & 0 & 1 \\
\hline & $\sum$ & 5 & 4 & 7 & 3 & 3 & & 7 & 1 & 6 & 36 \\
\hline \multirow{7}{*}{ 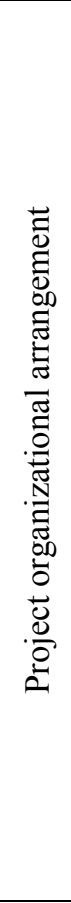 } & $\begin{array}{l}\text { Organiza- } \\
\text { tional stand- } \\
\text { ards to sup- } \\
\text { port PM }\end{array}$ & 0 & 1 & 1 & 1 & 1 & & 1 & 1 & 0 & 6 \\
\hline & $\begin{array}{c}\text { Project man- } \\
\text { agement } \\
\text { office }\end{array}$ & 0 & 0 & 0 & 0 & 0 & & 0 & 1 & 0 & 1 \\
\hline & $\begin{array}{l}\text { Matrix or- } \\
\text { ganizational } \\
\text { structure }\end{array}$ & 1 & 1 & 0 & 1 & 1 & & 1 & 0 & 1 & 6 \\
\hline & $\begin{array}{c}\text { Project or- } \\
\text { ganizational } \\
\text { structure }\end{array}$ & 0 & 0 & 1 & 0 & 0 & & 0 & 0 & 0 & 1 \\
\hline & $\begin{array}{c}\text { Staff educa- } \\
\text { tion in PM }\end{array}$ & 0 & 1 & 1 & 1 & 0 & & 1 & 0 & 0 & 4 \\
\hline & \begin{tabular}{|c|} 
Use of out- \\
side advisors \\
and project \\
managers \\
\end{tabular} & 1 & 0 & 1 & 1 & 1 & & 1 & 0 & 0 & 5 \\
\hline & $\sum$ & 2 & 3 & 4 & 4 & 3 & & 4 & 2 & 1 & 23 \\
\hline \multirow{2}{*}{ 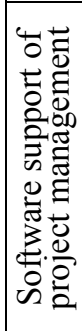 } & $\begin{array}{c}\text { Simple cloud } \\
\text { or freeware } \\
\text { solutions }\end{array}$ & 0 & 0 & 0 & 0 & 0 & & 0 & 0 & 1 & 1 \\
\hline & $\begin{array}{c}\text { Specialized } \\
\text { application } \\
\text { with a wide } \\
\text { range of } \\
\text { functionality }\end{array}$ & 0 & 1 & 1 & 1 & 0 & & 1 & 0 & 0 & 4 \\
\hline
\end{tabular}


End of Table 3

\begin{tabular}{|c|c|c|c|c|c|c|c|c|c|c|c|c|}
\hline \multirow{2}{*}{ 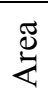 } & \multirow{2}{*}{$\begin{array}{l}\text { PM methods } \\
\text { and tools }\end{array}$} & \multicolumn{10}{|c|}{ Company } & \multirow{2}{*}{$\sum$} \\
\hline & & A & B & $\mathrm{C}$ & D & E & $\mathrm{F}$ & $\mathrm{G}$ & $\mathrm{H}$ & A & B & \\
\hline & $\begin{array}{l}\text { Complex SW } \\
\text { support of PM }\end{array}$ & 0 & 0 & 0 & 0 & 0 & & & 0 & 0 & 0 & 0 \\
\hline & $\sum$ & 0 & 1 & 1 & 1 & 0 & & & 1 & 0 & 1 & 5 \\
\hline & $\sum$ & 13 & 13 & 25 & 12 & 13 & & & 25 & 8 & 15 & 124 \\
\hline
\end{tabular}

In the area of time management, six of the monitored companies do not apply any methods or tools intended for this area. Only companies C and $\mathrm{F}$ make use of some of the methods and tools for project time management. In both cases, they apply the Gantt Chart and the Critical Path Method, and company $\mathrm{C}$ uses the Critical Chain Method on top of that.

In the area of source management, the situation is better than in the previous area. All the companies apply at least one of the source management methods or tools (and the Responsibility Assignment Matrix is used by all the monitored companies). In the case of company $\mathrm{E}$, it even makes use of all the assessed source management methods and tools.

In the area of cost management, all the companies monitor project costs and cash flows. Most companies (with the exception of company $\mathrm{G})$ also apply some of the other cost management methods. Primarily, they make use of the Net Present Value, or the Cost-Benefit Analysis, for assessment of the project intent or subsequent project evaluation.

In the area of risk management, two of the monitored companies (D and E) do not use any of the methods and tools intended for this area. The other companies use at least one of the assessed risk management methods and tools, and company $\mathrm{C}$ uses them to the largest extent. As for the methods and tools applied in this area, it is mainly the Risk Breakdown Structure and Determination of the Expected Value of the Risk.

In the area of scope management, the assessed methods and tools are applied to different extents, but each of the monitored companies uses at least one of these methods or tools. To the largest extent they are applied by companies $\mathrm{C}$ and F. The most widely applied methods and tools are those intended for the project preparatory stage (the SWOT Analysis, the SMART Method and the Feasibility Study), the implementation stage (the Milestone Trend Analysis), and the stage of application of project outputs (the Lessons Learned). On the other hand, the methods and tools that are used minimally only are those intended for project planning (the Product Breakdown Structure is not used by any of the monitored companies, and the Work Breakdown Structure is used by company F only).

As for the organizational arrangement of projects, including education of workers, each of the monitored companies applies at least one of the assessed tools suitable for this area. Most of the monitored companies apply the organizational standards to support PM, and projects are managed within the matrix organizational structure. The companies also make use of outside advisors and outside project managers.

SW support of PM is used by five of the eight monitored companies. If companies use SW support, it is usually in the form of applications with a wide range of functionality (e.g. MS Project). However, when comparing the scope of PM methods and tools applied in individual areas, it is possible to draw a conclusion that these SW applications are not used to the full extent of their functionality.

The performed survey implies that the level of PM in the monitored chemical industry companies in the Czech Republic from the point of view of the application of PM methods and tools is low. At least one of the monitored companies does not apply any of the assessed PM methods or tools in the areas of project time management, project risk management, and PM SW support. Therefore, $\mathrm{H} 2$ did not prove to be true.

\subsection{Proposed methodical measures to be taken by chemical industry companies in the area of project management}

To increase the level of PM in the chemical industry companies in the Czech Republic, it seems to be purposeful to implement changes in the form of the following measures:

- staff education in the area of PM: continuous training of workers in the area of PM using outside specialists; use of outside advisors and outside project managers to get experience with PM; use of certifications of some of the international standards to increase and unify the qualification of workers;

- creation or extension of organizational standards to support PM: creation of organizational standards using the international standards in the form of unified PM application procedures on the level of the organization as a whole; integration of PM methods and tools into the 
process steps defined within the organizational standards; introduction and active utilization of SW applications to support PM in a wide range of the offered functions to unify procedures within organizational standards;

- application of PM methods and tools in individual project lifecycle stages: formulating project plans using the Feasibility Study; defining project objectives using the SMART Method; planning projects in the form of partial plans; using network diagrams, or the Critical Chain Method to structure the project outputs and to draw up a schedule; using hierarchical structure of sources for planning sources, analyzing availability of sources, and projection of source availability into the time schedule in the way to achieve the most accurate possible project planning; in the course of implementation, project monitoring using suitable PM methods and tools to obtain more precise overview of the generated value in relation to the time schedule and spent means; regular evaluation of projects and use of the experience with project implementation for updating organizational standards and for management of the following projects;

- creation of the project environment that will include: generally increased pressure on observing the project triple imperative; application of the Net Present Value, and potentially other methods for making decisions on implementation of investment projects and for the subsequent audit when project implementation has been completed; application of the Cost-Benefit Analysis to make decisions on implementation of projects that do not create any financial yields and for the subsequent audit when project implementation has been completed; incorporation of the project approach into the strategic management of the company.

It is suitable to introduce the above methodical measures gradually in the way it is always possible to verify the change in question in practice, and if need be to make any necessary corrections in accordance with the current needs of the company.
Specifically, in the area of projects co-financed by EF, it is suitable to introduce further partial measures step by step to eliminate identified problems and to enable smooth preparation of applications and implementation of these projects. In the area of projects co-financed by EF, it is possible to recommend, apart from the application of measures useful for projects in general, the following further measures:

- to continue to use specialized outside advisory companies, or to specialize the staff in these problems purposefully to make it possible to monitor the current information in the area of providing support and to prevent potential problems connected with non-observance of the set rules resulting from ignorance of the problems;

- to make these specialized workers familiar with the conditions of provision of support also from other sources on the European level;

- to make use of SW applications to support PM for the reason of simplification of the administrative demands, automation of some monitoring activities and acquisition of a complete database of solved projects for assessment of the project portfolio and application of the method of Lessons Learned;

- within fulfilment of the strategic objectives on the level of the company, to make a more frequent assessment of the possibility of utilization of the European Fund sources for implementation of projects leading to the fulfilment of these strategic objectives.

Any methodical measures, no matter whether in projects generally or in projects co-financed by EF, must be taken with respect to the particular conditions of the given company. Primarily, their introduction should always be accompanied by the assessment of the short-term and longterm positive effects of the application of the given measure, and whether it will be a source of actual benefits for the company.

\section{Conclusions}

The paper deals with the problems of application of PM methods and tools by selected chemical industry companies in the Czech Republic within projects in general, and specifically within projects co-financed by EF. The theory of PM offers 
a wide range of methods and tools, whose application increases the success of project implementation. It is possible to use them:

- for management of projects companies solve commonly within their business activity,

- for management of a specific type of projects in the form of projects cofinanced by the EU funds.

As the paper implies, the companies make use, for management of both these types of projects, of the same PM methods and tools. Therefore, $\mathrm{H} 1 \mathrm{did}$ not prove to be true.

The level of knowledge and the scope of application of PM methods and tools differ:

- from the point of view of individual countries,

- from the point of view of the sectors or industries of the national economy,

- from the point of view of individual companies.

The paper implies that the level of PM in the chemical industry companies in the Czech Republic is, from the point of view of the application of PM methods and tools, low, and it is necessary to implement the changes proposed by the paper gradually. In fact, at least one of the monitored companies does not apply any of the assessed PM methods or tools in the areas of project time management, project risk management, and SW support of PM. H2 thus did not prove to be true.

The paper presents the outcomes of the survey focussed on the application of PM methods and tools by selected chemical industry companies in the Czech Republic. Its limiting factor is mainly the limited number of respondents. However, it brings original findings from the point of view of the chosen industry of the national economy of a small post-communist economy, which can mainly be used for comparison with other the post-communist EU member states. Next research could thus be focussed on analysis and assessment of PM methods and tools in other industries, or on the comparison on the level of the EU.

\section{References}

Association for Project Management. (2012). APM body of knowledge ( $6^{\text {th }}$ ed.). Rirborough: Association for Project Management.

Association of Chemical Industry of the Czech Republic. (2014). List of members. Retrieved from http://www.schp.cz/katalog.html
Atkinson, R. (1999). Project management: cost, time and quality, two best guesses and a phenomenon, it's time to accept other success criteria. International Journal of Project Management, 17(6), 337-342. https://doi.org/10.1016/S0263-7863(98)00069-6

Barker, S., \& Cole, R. (2007). Project management for practice $\left(1^{\text {st }}\right.$ ed.). Prague: Grada Publishing.

Beck, K., Beedle, M., A. van Bennekum, A., Cockburn, A., Cunningham, W., Fowler, M., Grenning, J., Highsmith, J., Hunt, A., Jeffries, R., Kern, J., Marick, B., Martin, R. C., Mellor, S., Schwa-ber, K., Sutherland, J., \& Thomas, D. (2001). Manifesto for agile software development. Retrieved from http://www. agilemanifesto.org/

Blazek, L. (2014). Management ( $2^{\text {nd }}$ ed.). Prague: Grada Publishing.

Carrilo, P., Ruikar, K., \& Fuller, P. (2013). When will we learn? Improving lessons learned practice in construction. International Journal of Project Management, 31(4), 567-578. https://doi.org/10.1016/j.ijproman.2012.10.005

Dolezal, J., Machal, P., Lacko, B., Hajek, M., Hrazdilova Bockova, K., Kratky, J., Nechvilova, S., Pitas, J., Tetrevova, L., \& Cingl, O. (2012). Project management according to IPMA ( $2^{\text {nd }}$ ed.). Prague: Grada Publishing.

Ernst \& Young. (2013). Project Management in the Czech Republic and Slovak Republic. Retrieved from http://www.ey.com/Publication/vwLUAssets/Pr\%C5 \%AFzkum_\%C5\%99\%C3\%ADzen\%C3\%AD_2013/\$ FILE/EY_Pruzkum\%20rizeni\%20projektu\%20v\%20 CR\%20a\% $\%$ 20SR\%202013.pdf

Goldratt, E. M. (1999). Critical chain ( $1^{\text {st }}$ ed.). Prague: InterQuality.

Gross, I. (2009). Mathematic models for managerial decision making ( $1^{\text {st }}$ ed.). Prague: University of Chemistry and Technology.

Hapanova, T., \& Al-Jiburi, S. (2009). Identifying key performance indicators for use in control of pre-project stage process in construction. International Journal of Productivity and Performance Management, 58(2), 160-173. https://doi.org/10.1108/17410400910928743

Hillier, F. S., \& Lieberman, H. (2005). Introduction to operations research ( $8^{\text {th }}$ ed.). New York: McGraw-Hill.

Hrazdilova Bockova, K. (2009). Future scenarios of Czech project management. E+M Economics and Management, 12(3), 6-18.

Jugdev, K. (2012). Learning from lessons learned: Project management research programme. American Journal of Economics and Business Administration, 4(1), 1322. https://doi.org/10.3844/ajebasp.2012.13.22

Katsarova, I. (2013). The (low) absorption of EU Structural Funds. Library of the European Parliament. Retrieved from http://www.europarl.europa.eu/eplibrary/Thelow-absorption-of-EU-Structural-Funds.pdf

Kostalova, J. (2015). The assessment of the project management maturity in the Czech Republic with focus on projects co-financed by European Funds and projects of the chemical industry enterprises: $\mathrm{PhD}$ diss. University of Pardubice.

Kostalova, J., Tetrevova, L., \& Patak, M. (2015). The system of support for projects co-financed by EU funds in the Czech Republic. Transylvanian Review of Administrative Sciences, 45E (June), 97-115.

Kostalova, J., Tetrevova, L., \& Patak, M. (2017). Project management methods in projects co-financed by EU 
funds in the Czech Republic. Engineering Economics, 28(3), 301-310.

https://doi.org/10.5755/j01.ee.28.3.13651

Kratky, J., Arazimova, M., Havlik, T., Krucky, P., Olbrich, L., \& Vondrackova, P. (2012). The report on project management in the Czech Republic $2012\left(1^{\text {st }}\right.$ ed.). Brno: The Czech Project Management Association.

Lacko, B. (2014). RIPRAN. Retrieved from http://www. ripran.cz/popis.html

Lee-Kwang, H., \& Favrel, J. (1988). The SSD graph: A tool for project scheduling and visualization, IEEE Transactions on Engineering Management, 35(1), 25-29. https://doi.org/10.1109/17.6001

Maravas, A., \& Pantouvakis, J. (2012). Project cash flow analysis in the presence of uncertainty in activity duration and cost. International Journal of Project Management, 30(3), 374-384. https://doi.org/10.1016/j.ijproman.2011.08.005

Maylor, H. (2010). Project management (4 ${ }^{\text {th }}$ ed.). Harlow: Pearson Education.

Melnic, A., \& Puiu, T. (2011). The Management of human resources within projects: The structures of the project team, the Responsibility Assignment Matrix. Economy Transdisciplinary Cognition, 14(1), 476-484.

Meredith, J. R., \& Mantel, S. J. (2012). Project management: A managerial approach. Hoboken: John Wiley \& Sons.

Ministry of Regional Development CZ. (2014). A monitoring report - December 2013. Retrieved from http://www.strukturalni-fondy.cz/cs/Informace-ocerpani/Mesicni-monitorovaci-zprava.aspx

Müller, R., Glückler, J., \& Aubry, M. (2013). A relational typology of project management offices. Project Management Journal, 44(1), 59-76.

https://doi.org/10.1002/pmj.21321

Norman, E. S., Brotherton, S. A., \& Fried, R. T. (2008). Work breakdown structures: The foundation for project management excellence ( $1^{\text {st }}$ ed.). Hoboken: John Wiley \& Sons.

https://doi.org/10.1002/9780470432723

Patanakul, P., Iewwongcharoen, B., \& Milosevic, D. (2010). An empirical study on the use of project management tools and techniques across project lifecycle and their impact on project success, Journal of General Management, 35(3), 41-65.

https://doi.org/10.1177/030630701003500304
Pitas, J., Stanicek, Z., Hajkr, J., Motal, M., Machal, P., Novak, I., \& Havlik, J. (2012). National standard competences of project management - version $3.2\left(1^{\text {st }} \mathrm{ed}\right.$.). Brno: The Czech Project Management Association.

Project Management Institute. (2004). A guide to the project management body of knowledge ( $3^{\text {rd }}$ ed.). Newton Square: PMI.

Ravindran, A. R. (2008). Operations research and management science handbook ( $1^{\text {st }}$ ed.). Boca Raton: Taylor \& Francis Group.

Robbins, S. P., \& Coulter, M. (2004). Management ( $7^{\text {th }}$ ed.). Prague: Grada Publishing.

Solanki, P. (2009). Earned value management: Integrated view of cost and schedule performance $\left(1^{\text {st }} \mathrm{ed}\right.$.). New Delhi: Global India Publications.

Storms, K. (2008). Earned Value Management implementation in an agency capital improvement program. Cost Engineering, 50(12), 17-40.

Svecova, L. (2013). Multi-criteria risk assessment (Habilitation theses). University of Economics, Prague.

Svozilova, A. (2011). Project management ( $2^{\text {nd }}$ ed.). Prague: Grada Publishing.

Tetrevova, L. (2006). Projects financing ( $1^{\text {st }}$ ed.). Prague: Professional Publishing.

Tetrevova, L. (2008). Public economics ( $1^{\text {st }}$ ed.). Prague: Professional Publishing.

Trietsch, D., \& Baker, K. R. (2012). PERT 21: Fitting PERT/CPM for use in the $21^{\text {st }}$ century. International Journal of Project Management, 30(4), 490-502. https://doi.org/10.1016/j.ijproman.2011.09.004

Unger, B. N., Gemünden, H. G., \& Aubry, M. (2012). The three roles of a project portfolio management office: Their impact on portfolio management execution and success. International Journal of Project Management, 30(5), 608-620. https://doi.org/10.1016/j.ijproman.2012.01.015

Veber, J., Fotr, J., Kotoucova, J., Maly, M., Mladkova, L., Novy, I., Nemec, P., Svecova, L., \& Vodacek, L. (2009). Management ( $2^{\text {nd }}$ ed.). Prague: Management Press.

Vitous, M. (2012). Implementation of project management systems. IT Systems, 14(9), 32-33. Retrieved from https://www.systemonline.cz/rizeni-projektu/implementace-systemu-na-podporu-projektoveho-rizeni.htm

Zandhuis, A., \& Stellingwerf, R. (2013). ISO 21500: Guidance on project management - a pocket guide ( $1^{\text {st }}$ ed.). Zaltbommel: Van Haren Publishing. 